\title{
The Effect of Natural Aromatase Blockers on the Testicle Weight, Size of Wattle and Histopathological of Testis In Bangkok
}

\author{
Pudji Astuti ${ }^{1 *}$, Claude Mona Airin ${ }^{1}$, RR Amelia Hana ${ }^{1}$, Rizki Fitrawan Yuneldi ${ }^{2}$, and \\ Sarmin $^{1}$ \\ ${ }^{1}$ Department of Physiology, Faculty of Veterinary Medicine, Universitas Gadjah Mada, Indonesia \\ ${ }^{2}$ Postgraduate Student, Faculty of Veterinary Medicine, Universitas Gadjah Mada, Indonesia
}

\begin{abstract}
The aromatase enzyme is an enzyme that converts testosterone to estrogen. This means that by administering aromatase blockers, testosterone levels increase and estrogen levels decrease. The problem faced is how the spermatogenesis process occurs because estrogen is needed as well in the process. This study aimed to evaluate the histopathological features of the testes due to the administration of natural aromatase blockers (NAB). Fifteen male Bangkok chickens were divided into 5 groups, namely: control group (C); testosterone continues (Tc $0.4 \mathrm{mg} / \mathrm{bird} / \mathrm{day})$; natural aromatase blockers 33 (NAB $3.3 \mathrm{~g} / \mathrm{bird}$ ); natural aromatase blockers 66 (NAB $6.6 \mathrm{~g} / \mathrm{bird}$ ); zinc ( $\mathrm{Zn}): 0.45 \mathrm{mg} / \mathrm{kg}$ body weight (BW). The oral treatment was given for 35 days. The results showed that NAB did not affect wattle growth, but significantly affected testicle weight ( $\mathrm{p}$-value $<0.05$ ). The NAB 66 group had the heaviest testis weight, followed by zinc, continuous testosterone, NAB 33 group, and the control group. This results was confirmed by HE staining on the testes which showed the thickness of the thickest spermatogenic and spermatid cell layers in the NAB 66 group. It was concluded that giving NAB did not harm the spermatogenesis process.
\end{abstract}

\section{Introduction}

Indonesia Ministry of Agriculture (KEMENTAN) in 2019 started the distribution of Super Javanese chickens or commonly called Joper chickens in order to increase the performance of poultry. This type of chicken is a crossing result of a purebred hen and a male Bangkok chicken. The performance of roosters, especially Bangkok chickens, is highly affected by testosterone (T), a hormone produced by Leydig cells and has got an important role in the spermatogenesis process. The virility and libido of roosters were influenced by testosterone found in the medial preoptic area, HVC, the dopaminergic cell group. While for the voice, it is controlled by testosterone in the syrinx. Unfortunately, some of the testosterone in the body will be converted into estrogen by the aromatase enzyme. Therefore, the high amount of

*Corresponding author : pastuti2@ugm.ac.id 
testosterone in the body cannot be maintained continuously. On the other hand, giving testosterone continuously for a long time could result in down-regulation and the opposite effect. Thus direct testosterone administration is not recommended.

The administration of natural aromatase blockers to mice [1] and canaries could increase testosterone levels including quality and quantity of sound [2]. Previous researchers considered that estrogen is only important for female animals. Whereas, in male animals, the importance of estrogen has not been much revealed. As time goes by, it has been found that estrogens are believed to act very important roles in the normal development of male gonad function, spermatogenesis by controlling stem cell numbers, and maturation of spermatids in the seminiferous tubules [3]. From this statement, research will be carried out that examines the effect of giving natural aromatase blockers (NAB) on the histopathological features of the testes.

Oysters are known as the mineral's potent testosterone-boosting abilities [4]. So far, only the meat is used, while the shell is just thrown away, even though the oyster shell is very rich in zinc as an aromatase blocker. The advantages of this research are also revealed by providing natural ingredients so it would not interfere the health. Therefore, oyster shell waste will be utilized as Bangkok chicken feed to improve the performance. A waste that turned into a blessing. This study aimed to evaluate the histopathological features of the testes due to the administration of natural aromatase blockers. Hopefully, the administration of natural aromatase blockers (NAB) could increase testosterone by stopping the conversion to estrogen without causing spermatogenesis disorders.

\section{Materials and methods}

\subsection{Animal Model}

The animal used for the study was a Bangkok chicken aged 1 year, with several considerations such as the reaction to steroid hormone (testosterone) on the performance of Bangkok chickens can be clearly identified. Performance improvement can be seen by measuring the weight of the testes, wattle, and the histopathological features of the testes. Fifteen Bangkok chickens were divided into groups to receive the following treatment. Group I as control, while groups II, III, IV, and V received oyster shell treatment in different doses. Group I was given standard feed, group II was given testosterone continues (Tc) at a dose of $4 \mathrm{mg} / \mathrm{bird} /$ day [5]. Oyster shells of Anadara nodifera, each with a dose of $3.3 \mathrm{~g} / \mathrm{bird}$ (group III) and $6.6 \mathrm{~g} / \mathrm{bird}$ (group IV) were mixed into the feed. Group V given zinc (Zn) at a dose of $0.45 \mathrm{mg} / \mathrm{kg} \mathrm{BW}$ [6]. The treatment was carried out for 35 days. On the last day, the chickens were sacrificed using ketamine silacin in excess doses. The next step is drawing blood, making serum to measure blood testosterone levels and taking the testicular organs, measuring testicular weight, and measuring the wattle.

\subsection{Wattle Measurement}

The measurement of the wattle is done by measuring the longest part of the wattle (length) and measuring the highest part of the wattle (width). Each measurement was done 3 times then the mean was calculated. The size of the wattle is done by multiplying the length $\mathrm{x}$ width $\left(\mathrm{cm}^{2}\right)$. 


\subsection{Weighing Testes and Making Histopathological Features}

Both testes were taken from the body, weighed 3 times, then the mean was calculated. The left and right testes were taken and weighed, then put in a Bouin solution. Furthermore, the hematoxylin-eosin (HE) staining was performed. All research implementation procedures have received approval from the LPPT Preclinical Ethics Commission, with number 00030/04/LPPT/IV/2020.

\section{Result and discussion}

\subsection{Effect of NAB Treatment on Wattle Size}

The size of the wattle as a result of the administration of NAB can be seen in Table 1. After a statistical test was carried out, it could be proven that NAB did not lead to the accelerated growth of wattle size (p-value > 0.05). Otoo et al. [7] stated that the growth of wattle or comb in male chickens is highly dependent on the testosterone produced by Leydig cells in the testes. The testosterone produced will be secreted and transported to the comb and will grow. Although it is anticipated that by giving NAB, the Testosterone level will increase, it was not able to increase the size of the wattle. This could be due to the age of the chickens used, which is one year old or more. Therefore, the wattle growth did not occur optimally.

Table 1. Wattle Size in Each Group during the Treatment $\left(\mathrm{cm}^{2}\right)$

\begin{tabular}{ll}
\hline Treatment Group & Size of Wattle $\left(\mathrm{cm}^{2}\right) \pm$ SD \\
\hline C & $4.13 \pm 0,07^{\mathrm{a}}$ \\
Tc & $6.69 \pm 1.21^{\mathrm{a}}$ \\
NAB 33 & $5.89 \pm 0.96^{\mathrm{a}}$ \\
NAB 66 & $5.76 \pm 0,89^{\mathrm{a}}$ \\
Zn & $5.97 \pm 2.04^{\mathrm{a}}$ \\
\hline \multicolumn{2}{c}{${ }^{\mathrm{a}-\mathrm{c}}$ shows difference significant of p-value $(\mathrm{p}$-value $<0.05)}$.
\end{tabular}

Added by Shen et al. [8] and Yuneldi et al. [6], testosterone can stimulate the height of the wattle's growth. Exogenous testosterone can stimulate wattle growth quickly [9]. Following the opinion of Rizzi and Verdiglione [10], the size of wattle is positively correlated with testosterone levels. This is probably caused by the difference growth time between wattle height compared to wattle length which requires a longer time, so the effect has not been detected yet.

\subsection{Effect of NAB Treatment on Testicular Weight}

The testicle is the main organ producing testosterone. There is a positive correlation between testosterone levels and testicular weights [11]. The results showed that the NAB 66 group obtained the heaviest testicle weight among others, $26.39 \pm 4.14$ gram. The longer period of the administration of testosterone, the weight of the testicle decreased with a significant difference compared to $\mathrm{P} 0$ and other groups $(\mathrm{P}<0.05)$ (Table 2). 
Table 2. Testicular Weight in Each Group during the Treatment $(\mathrm{g})$

\begin{tabular}{ll}
\hline Treatment Group & Testiscle weight $(\mathrm{g}) \pm \mathrm{SD}$ \\
\hline $\mathrm{C}$ & $14.67 \pm 1.66^{\mathrm{b}}$ \\
Tc & $16.04 \pm 2.07^{\mathrm{b}}$ \\
NAB 33 & $14.30 \pm 3.67^{\mathrm{b}}$ \\
NAB 66 & $26.39 \pm 4.14^{\mathrm{a}}$ \\
Zn & $19.30 \pm 2.73^{\mathrm{a}}$ \\
\hline \multicolumn{2}{c}{${ }^{\mathrm{a}-\mathrm{c}}$ shows difference significant of p-value (p-value $\left.<0.05\right)}$.
\end{tabular}

It has been explained previously that the administration of testosterone in small amounts continuously can result in the inactivity of the testes. In this case, the shrinking of the testicles may also make down-regulation so that the longer the administration of testosterone will reduce the weight of the testes. Based on Palacios et al. [12] continuous testosterone administration could decreased testicular weight.

\subsection{Effect of NAB Treatment on Testicles Histopathological Features}

Testicular histopathological features were obtained to determine the effect of NAB administration on the process and production of spermatozoa in the testes. In this study, the results showed that the spermatogenic cell layer (A) and spermatid cell layer (B) in the NAB 66 group had a thicker layer than the other groups (Fig.1). These findings are similar to previous studies which explained that in humans, giving aromatase blockers can improve the Testosterone or Estrogen ratio. This means that giving aromatase blockers can increase the concentration of spermatozoa and motility of spermatozoa [3].

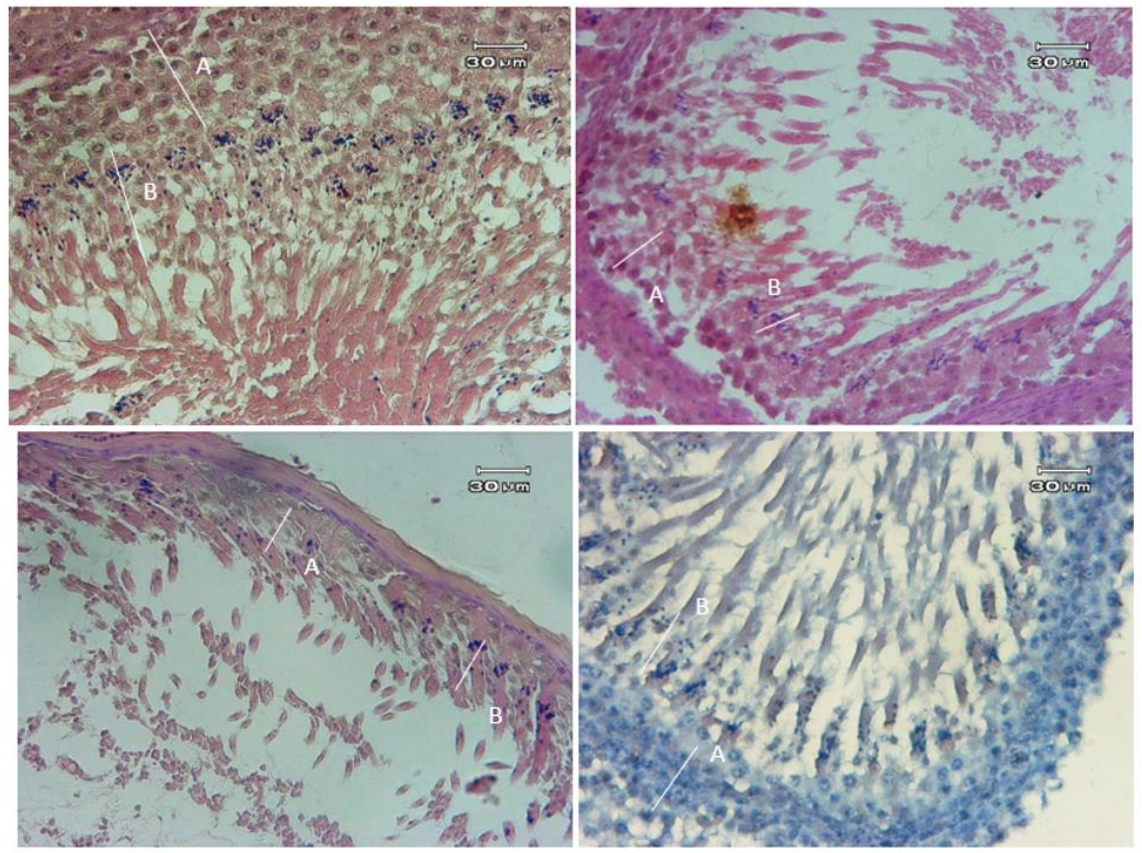

Fig. 1. Top left: NAB 66; Top right: NAB 33; Bottom left: Zn; Bottom right: control. Spermatogenic cell thickness (A), spematid cell thickness (B) in Group NAB 66. While the other groups had similar thickness. 
Spermatogenic and spermatid cells are candidates for spermatozoa. It means that the more and thicker the consistency is, the spermatozoa concentration is expected to increase. On the other hand, the spermatogenesis process is greatly influenced by Testosterone. In this study, the levels of Testosterone in the Group NAB 66 group were also very high (unpublished data) strongly correlated with the density of spermatogenic (A) and spermatid (B) cells as shown in Fig.1.

\section{Conclusion}

It was concluded that giving NAB did not harm the spermatogenesis process. It is necessary to do further research on the effect of NAB given on the process of spermatozoa maturation. The sample should be taken from cauda epididymis and evaluate the abnormalities of spermatozoa.

\section{References}

1. P. Astuti, C. M. Airin, S. Sarmin, A. Nururrozi, and S. Harimurti, Vet. World 12, 1677 (2019)

2. P. Astuti, C. M. Airin, A. Nurrurozi, R. Aidi, A. Hana, S. Hadi, and H. Harimurti, in E3S Web Conf. (2020), pp. 2019-2021

3. M. Schulster, A. M. Bernie, and R. Ramasamy, Asian J. Androl. 18, 435 (2016)

4. J. Blakemore and F. Naftolin, Physiology 31, 258 (2016)

5. Andriyanto, A. S. Satyaningtijas, R. Yufiandri, R. Wulandari, V. M. Darwin, and S. N. A. Siburi, Acta Vet. Indones. 3, 29 (2016)

6. R. F. Yuneldi, C. M. Airin, H. T. Saragih, and P. Astuti, Key Eng. Mater. 884, 252 (2021)

7. L. Otoo, G. Koffuor, C. Ansah, K. Mensah, C. Benneh, and I. Ben, J. Intercult. Ethnopharmacol. 4, 293 (2015)

8. M. Shen, L. Qu, M. Ma, T. Dou, J. Lu, J. Guo, Y. Hu, G. Yi, J. Yuan, C. Sun, K. Wang, and N. Yang, PLoS One 11, 1 (2016)

9. K. Yoshioka, Y. Watahiki, A. Kanie, M. Tsujio, H. Ikadai, T. Kashimoto, and K. Mutoh, Br. Poult. Sci. 51, 185 (2010)

10. C. Rizzi and R. Verdiglione, Ital. J. Anim. Sci. 14, 266 (2015)

11. P. Astuti, B. A. Fajar, M. Mauludin, A. Hana, C. M. Airin, S. Sarmin, and S. Harimurti, Int. J. Poult. Sci. 14, 639 (2015)

12. A. Palacios, R. D. McClure, A. Campfield, and R. S. Swerdloff, J. Urol. 126, 46 (1981) 